\title{
ROLDÁN ESTEVA-GRILLET
}

\author{
$\Gamma 1$ \\ Iconografia Euro-Americana \\ de Bolívar \\ Tradução: Alberto Coelho \\ Revisão: Vinícius Godoy
}

RESUMO

O artigo oferece um estudo crítico dos retratos dedicados a Simon Bolívar, observando diversos momentos na elaboração de sua iconografia. Ainda que se trate de uma produção realizada essencialmente por artistas americanos, o autor observa também a participação que teve neste âmbito a obra de artistas-viajantes. Atendendo as circunstâncias em que surgiram as diversas representações desta importante figura da independência americana, se discutem as conotações biográficas e políticas destes registros, até chegar ao presente, em que 0 crescente bolivarianismo chega a interferir no comércio artístico deste tipo de obra.

PALAVRAS-CHAVE

Bolívar; retratos; política, bolivarismo; fFalsificação. 
ARCINIEGAS, Germán. Bolívar, de San Jacinto a Santa Marta. Juventud y muerte del Libertador. Bogotá: Planeta; 1988, p. 157.
Em principio do ano de 1799 zarpava do porto venezuelano de Guairá, o barco San Ildelfonso, dirigia-se até o porto espanhol de La Curuña, mas fazendo antes uma escala em dois importantes portos do Caribe: Veracruz e La Habana. Embarcou um adolescente que mesmo sem haver completado seus dezesseis anos já era subtenente de milícias de blancos e possuidor de uma importante fortuna, pelo menos no papel. Somente depois de casar-se é que poderia obter sua posse. Seu nome Simón Antonio de la Santíssima Trinidad Bolívar y Palácios, conhecido hoje como Simón Bolívar. Era órfão de pai e mãe, e sua educação, extremamente informal, havia ficado nas mãos de tutores privados entre os quais estavam os padres Andujar, Andrés Bello e o inigualável, além de xará, Simón Rodríguez. Os tutores legais e administradores de sua fortuna, tios maternos, decidem, pois enviar-lo a Espanha para refinar sua maneiras e modelar seu pensamento.'

Foi então que teve início uma itinerância que será constante na vida deste personagem. Ao estudar sua iconografia, constatamos que este ir e vir nos coloca frente a uma situação singular: Bolívar passou a ser um motivo artístico viajante, retratado desde sua terna adolescência, em Madrid, até os dias de despedida do poder, em terras sul-americanas. Com bastantes sobressaltos se foi criando uma tradição de registro desta figura; se trata de um rico conjunto de imagens reunido pela primeira vez, faz agora exatamente 50 anos, em um monumental trabalho de Alfredo Boulton, e publicado sob o título de Los retratos de Bolívar.

Graças a Boulton os venezuelanos têm conhecido os melhores e mais autênticos retratos de Bolívar, no entanto é bom já adiantar que, graças a difusão de tais imagens, é cada vez mais dificil determinar quais, entre as muitas que começaram a aparecer, podem ser consideradas verdadeiras, quer dizer, correspondentes a época ou realizadas na presença do personagem.

O método seguido por Boulton era aparentemente simples: só lhe interessavam aquelas imagens executadas quando Bolívar estava vivo e, sendo possível, tendo ele posado para o pintor ou desenhista. Sua obsessão pessoal era revelar o rosto de Bolívar, tal como havia ficado documentado em numerosos testemunhos da época, fundamentalmente em cartas ou memórias de pessoas que o conheceram de perto. Além disso, contava muito para Boulton o momento da descrição, quando o rosto foi se modificando com as transformações da guerra, o envelhecimento precoce e os estragos da doença - romântica como o século -, da qual seria vítima mortal: a tuberculose. Entre 
tantas descrições, uma é considerada a mais fidedigna quanto ao seu físico. E corresponde a um de seus mais fiéis ajudantes e biógrafos, o britânico Florence O'Leary:

El G'B tinha uma testa muito alta mas não muito larga. Tinha muitas rugas. As sobrancelhas eram grossas e bem formadas; os olhos escuros e penetrantes, o nariz largo e correto. Na metade dele teve uma pequena verruga que não foi visível até [18] 20, o que Ihe ocasionava alguma moléstia, a qual esqueceu depois que parou de crescer. Maças do rosto salientes e bochechas fundas desde que o conheci [maio 1818]. A boca era feia porque os lábios eram grossos e o superior alargado. Seus dentes eram parelhos, brancos e bonitos. Os cuidava com esmero. Mandíbulas e queixo proeminentes. Orelhas grandes. $O$ cabelo, nos anos de [18-19-20-2I] quando 0 mantinha longo [até que começou a branquear em 1822] era extremamente negro e cacheado. As costeletas e bigode [tinham] uma cor mais clara. Aparou o bigode em Potosí em 1825; era da mesma estatura que eu, não sei o que representaria hoje, algo como 5'6 e 5'7 [l,667 m ou l,702 m], era estreito de peito e toda sua figura era magra, em particular as pernas. A pele escura e áspera e seus pés e mãos notadamente pequenos e bonitos. ${ }^{2}$

Como bom praticante do método do atribucionismo no campo artístico, particularmente na arte colonial venezuelana, Boulton comparava retratos e buscava traços de estilo, mas também elementos identificadores dos tipos de representações: seja nas poses, seja nas vestimentas, seja na fisionomia. Assim, de um acúmulo enorme de retratos examinados in situ ou por fotografias, pode estabelecer diversos grupos. Basicamente seis: Bate; Gil; Anônimo peruano de 1825; Roulin; Espinosa; Meucci, com suas respectivas filiações ou derivados (cópias ou imitações); mais outro grupo com retratos sem vínculos entre si. Mas, desses duzentos e quarenta e seis retratos, apenas uma vintena podiam ter correspondido a retratos tomados ao natural ou pelo menos copiados de outros que eram originais. Por outra parte, como fotógrafo, Boulton documentava suas descobertas para poder estudá-las logo, com cuidado, em sua casa. Contava com uma folgada posição econômica, por pertencer a uma família de empresários de longa data no país, estando vinculado a notáveis colecionadores. De maneira que, se houvesse a necessidade em deslocar-se a qualquer lugar, podia fazê-lo com seus próprios recursos. Acrescentamos que, entre os dados mais importantes de cada retrato, anotava sua origem, como havia chegado às mãos do atual colecionista ou possuidor, seja por herança, doação ou compra. Por último, a análise artística em si mesma, como crítico de arte que era.

Detached Recollections of general Florence O'Leary (col. Francis A. 0 'Leary), reproduzido por R. A. Humphred publicado pela Universidad de Londres, 1969; segundo BOULTON, Alfredo. El rostro de Bolívar. Caracas: Ed. Macanao; 1982, p.I3. 
ESPINOSA José Maria. Memorias de un abanderado. Recuerdos de la patria Boba. I810-1819. Bogotá: Imprenta El Tradicionalista; 1876. Foi encarregado da redação de suas memórias 0 escritos José Caicedo Rojas.

Cf. segunda edição, Bogotá: 1969, p.80 (com prólogo de Germán Arciniegas).

Informada por BOULTON, quem sustenta que esse quadro seria uma réplica do original, enviado a sua irmã Maria Antonia em Caracas. A gravura foi impressa finalmente em 1827, e 0 quadro londrino regressou, através de Belford Wilson, em 1834, a Sucre, Bolívia.
Muitas referências chegam ao nosso experto bolivariano sobre o tema dos encargos de retratos ou o envio dos mesmos a regiões distantes, quando não a ajuda por parte do próprio Bolívar. Mas não há testemunhas - além de uns quantos recibos municipais, de pagamentos a determinados pintores em Bogotá (Pedro José Figueroa) e Lima (Pablo Rojas, José Pozo) - de que Bolívar tenha realizado acordos pessoais com algum dos retratistas, apesar de vários estarem a seu serviço no exército (os venezuelanos José de la Cruz Limardo, Juan Bautista Ugalde, José Peregrino Malcampo e Carmelo Fernandéz; os colombianos José Maria Espinosa e Pio Domingo del Castillo, o peruano José Gil de Castro). Em troca, graças a um deles, José Maria Espinosa, conhecemos o comportamento de Bolívar vendo-se diante da necessidade de posar para um retrato.

O pintor foi chamado ao Palácio San Carlos, em Bogotá, através de um tio, no início de agosto do ano de 1828, justo a um mês e meio antes do célebre atentado contra Bolívar, do qual o salva sua amante Manuelita Sáenz. Refere em suas memórias que, de oito sessões só pode aproveitar quatro horas. Recorda o conhecido miniaturista colombiano:

\section{Depois de apresentado a Bolivar, que me recebeu de forma carinhosa, ele se colocou a frente de mim com os braços cruzados: eu apenas começava o desenho quando ele me disse: Já está?; Ihe respondi que faltava muito: então esticou os braços, dizendo-me: Você pode vir quantas vezes quiser, as onze, antes que se reúna o conselho! ${ }^{3}$}

Em outra sessão, em que o Libertador não permanecia quieto, sugeriu o pintor que ele procurasse permanecer imóvel, e a resposta revelou bem a dificuldade apresentada a qualquer outro artista: Pretendes acaso que eu permaneça imóvel como uma estátua? ${ }^{4}$

Apesar de, em várias ocasiões, os retratos, particularmente as litografias, terem sido submetidos ao juízo e parecer do próprio Bolívar, a fim de evitar alterações em seu rosto, somente em uma ocasião ele elogiou sua imagem, a conseguida pelo pintor mulato em Lima, José Gil de Castro, em 1825. Bolívar envia uma réplica do quadro de corpo inteiro a Sir Robert Wilson, em Londres, este solicita uma litografia ao desenhista e gravador Charles Turner, que o faz introduzindo alguma variação no cenário. No dia 29 de outubro de 1825, de Potosí, escreve a Wilson, pai de seu ajudante Belford H. Wilson: Tomo a liberdade de dirigir a você meu retrato, feito em Lima com a maior exatidão e semelhança. ${ }^{5}$

A partir deste retrato, Bolívar aparecerá sempre sem bigode. Todos seus retratos, pelo menos desde o mais antigo, já como militar, dos anos 1812 ou 1813 , realizado possivelmente em Cartagena - antes de iniciar sua Campanha Admirável de reconquista do país, dominado por seu Decreto de Guerra a Morte -, brilha seus bons bigodes e suas grossas costeletas.

A pesquisa e compilação de testemunhos gráficos e pictóricos iniciada por Boulton em 1946, há sessenta anos, cujo primeiro produto - de 1956 - hoje comemoramos, foi 
enriquecendo-se com os anos; ao nome de nosso autor se acrescentaram outros estudiosos americanos, que em seus respectivos países haviam empreendido tarefa similar, ajudando em muito nas próprias buscas do investigador venezuelano. ${ }^{6}$ A diferença com seus colegas se mostra em diversos níveis: foi um empresário, colecionista de arte, também fotógrafo notável, mas sobretudo historiador e crítico de arte, ainda que sua única formação acadêmica foi obtida no campo do comércio. $O$ fato de pertencer a uma alta classe social e viver seus anos de formação na Europa do entre-guerras, lhe permitiu ser possuidor de uma cultura moderna e crítica. Seu rigor na revisão de fontes primárias e seus dotes de escritor o fizeram alcançar a condição de acadêmico de número de nossa Academia Nacional de História, de maneira que, sobre este assunto, vivemos às custas da informação de Boulton, só nos cabendo confrontá-las com investigações e análises próprias.

Concluamos este aparte recordando que também nesse ano de 1799, quando o adolescente Bolívar inicia seu primeiro périplo caribenho-europeu e o sábio Humboldt sobe as costas cumanesas, morre em Caracas o último maestro de pintura colonial, Antonio José Landaeta.

\section{Pintaram a Bolívar nossos pintores?}

A resposta de Boulton é taxativa: Não. A razão:

Retratos venezuelanos de Bolivar, estando Bolivar vivo, não há nenhum. Em primeiro lugar, ele não teria nenhum tempo para isso, e, segundo lugar, nos momentos da grande revolução da independência, os pintores estavam com um fuzil matando espanhóis. Não estavam pintando. ${ }^{7}$

Talvez valeria destacar algo, pois os fuzis não foram determinantes, inclusive houve batalhas como a de Junín, onde não se disparou uma só bala e tudo se resolveu a ponta de sabres e lanças. Eventualmente, resplandeciam os facões e as facas, mas raramente os primitivos arcos e flechas. Sem dúvida os tempos foram calamitosos para todos os ofícios e, no entanto nem todos foram os artífices alistados.

Em nossa própria revisão contabilizamos sete retratistas venezuelanos, contemporâneos a Bolívar. Sabemos com exatidão que somente dois deles se incorporaram ao exército, segundo o testemunho de suas próprias memórias. Cronologicamente o primeiro é José de La Cruz Limardo, nascido em Caracas em 1787 e falecido em El Tocuyo em I85I. Foi discípulo do pintor romano Onofre Padroni (ativo também no México) e se dedicou a miniatura, além do exercício da medicina que havia estudado na Universidade de Caracas. A guerra o obrigou a incorporar-se como ajudantede-ordens nas tropas de José Félix Ribas, tio político de Bolívar, no final de I8I2. Logo em Caracas foi secretário de Tomás Lander, futuro fundador do partido Liberal junto a Antonio Leocadio Guzmán. A emigração forçada dos caraquenhos em 1814, diante do

Na Colômbia, URDANETA, Alberto (I883), CUERVO, Luis Augusto (1919, 195I) e SANTOS, Eduardo; no Equador, AROCHA, Manuel (1943); no Peru, MOSTAJO, Francisco (1939) e UGALDE Y UGALDE, Joaquin (1949, 1952, 1953). Até o surgimento de BOULTON, na Venezuela, só haviam se ocupado do tema, GUZMÁN, Leocadio Antonio (1863), LANDAETA ROSALES, Manuel (1905, 1917), SÁNCHEZ, Manuel Segundo (1916) e LUCENA, Vicente (1950). Vários destes estudiosos possuíam retratos originais de Bolívar.

WISOTZKY, Ruben. "Nos seus 80 anos Alfredo Boulton continua descobrindo a Venezuela: ninguém conhece a cara do Grande Mariscal de Ayacucho", no Diário de Caracas: 28 de setembro de 1994. 


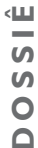

LIMARDO, José de la Cruz. "Memorias del Dr..." I, em Boletin de la Academia Nacional de la Historia, №. I28, Caracas: outobro-novembro 1949; e II no no. I3I, Caracas: julho-setembro 1950.

Cf. SALAS, Alejandro. "LIMARDO, José dela Cruz". Diccionario biográfico de las Artes Visuales en Venezuela. Tomo 2. Caracas: Fundação Galeria de Arte Nacional (patrocínio das Fundaçōes Cisneros e Cultura Urbana); 2005.

Cf. FERNÁNDEZ, Carmelo. Memorias. Caracas: Cooperativa de Artes Gráficas; 1940 e GONZálEz ARNAL, Maria Antonia. "FERNÁNDEZ, Carmelo", no Diccionario biográfico... (ob.cit), I tomo.

ESTEVA-GRILLET, Roldán. "A influência de Alejandro de Humbolldt em dois pintores venezuelanos: Carmelo Fernández e Ramón Bolet", em El asombro: viaje de Humboldt y Bonpland por Venezuela. Caracas: Galeria de Arte nacional (catá$\log 0) ; 1999$.

Cf. ESTEVA-GRILLET, Roldán. Vida y obra de Pedro Castillo (1790-1858), el pintor de la casa del general José Antonio Páez en Valencia. Caracas: Academia Nacional de História; 2004. ataque do feroz asturiano José Tomás Boves, o levou a exercer a medicina e a pintura de miniatura em várias ilhas do Caribe, para estar novamente de retorno ao país em I822. Em 1843 escreveu suas memórias. ${ }^{8}$ Lamentavelmente sua obra não foi estudada ou identificada; ainda que, se teve proximidade com o Dr. José Maria Vargas ${ }^{9}$, grande bolivariano, e havendo retratado a Bolívar, teria revelado.

Outro artista, tanto ilustrador como pintor, sobretudo aquarelista, foi Carmelo Fernández, nascido em Guama em 1809 e falecido em Caracas em I887. É o segundo pintor que deixa suas memórias, se bem que, pela própria vontade, só foram publicadas passados cinqüenta anos de sua morte. ${ }^{10}$ Foi o sobrinho de Páez quem o mandou a estudar nos Estados Unidos, onde recebeu aulas de um maestro italiano, Pinistre; no seu regresso ao país em 1827 seguiu os estudos militares na Comandância de Engenheiros, o que lhe permitiu incorporar-se ao exército. Para cortejar uma jovem deu de presente uma miniatura de Bolívar, de Meucci em 1830. Sua própria atividade de miniaturista fica registrada a partir do ano de 1833. Serviu como ilustrador do primeiro livro Atlas fisico y político de la república de Venezuela, escrito pelo italiano Agustín Codazzi, cientista com o qual volta a trabalhar na Comissão Corográfica de 1855 e para quem realiza as melhores aquarelas da época, segundo as prescrições de Humboldt para a ilustração científica do mundo natural." Sua imagem de Bolívar escapa da estrita contemporaneidade, pois corresponde a uma década posterior. Apesar de tê-lo conhecido (em três ocasiões esteve perto), colocado na tarefa de representá-lo para o Resumen de Historia de Venezuela de Ramón Diaz e Rafael Maria Beralt (I84I), recorre ao já famoso perfil do francês Roulin (1828).

Outro pintor, discípulo de José de la Cruz Limardo - ainda que não o mencione - e que teve o mesmo maestro italiano, é Pedro Castillo, nascido em Villa de Cura em 1790 e falecido em Valencia em 1858. Este sim foi mais estudado. Sua vinculação mais estreita foi com Páez. A razão é simples: é em Valencia donde radica e de onde governa Páez como Chefe Político e Militar durante a Grande Colombia. Ali, Castillo se encarregou de decorar a casa de Páez com murais alusivos a suas mais célebres batalhas, motivos mitológicos e paisagens, também fez retratos de seu amigo e mecenas, e de toda sua família. E, ainda que por questões políticas, nenhum desses retratos tenha sobrevivido, outros o revelam como um destacado fisionomista, a altura de um Gil de Castro. Em uma ocasião as circunstâncias da guerra o comprometeram a pintar os tambores de um substituto do terrível Boves, assentado em Valencia: Mompox. Próximo a sua morte, Castillo realizará um retrato de corpo inteiro de Bolívar para o Congresso (1856), se servindo para isso do confeccionado pelo francês Paulin Guerin (I842), versão que por sua vez valeu-se do retrato feito por Gil de Castro $(1825)^{12}$

Dois exímios miniaturistas, de obra quase desconhecida, foram Juan Bautista Ugalde e José Peregrino Malcampo. Do primeiro, nascido em 1808 , sabemos que era filho de 
um monarquista; esteve em Madrid estudando na Academia de San Fernando, com José Madrazo. Reapareceu na Bolívia formando parte da comitiva que acompanha o Libertador em 1825, de quem deixou um retrato (hoje em coleção privada), cuja filiação o relaciona com o Anônimo peruano deste ano. Na Venezuela, um senhor Mauri, de La Guairá, Ihe confiou uma miniatura, hoje conservada no Museu Bolivariano de Caracas, inspirada em Gil de Castro. Faleceu em Madrid, em 1860. Conta-se que a herança paterna foi dilapidada no jogo. ${ }^{13}$

Do segundo, nascido em 1808 e falecido em 1870 em Caracas, se sabe que, durante a última visita do Libertador, em 1827 - com a intenção de aplacar os ânimos turbulentos de Páez e evitar a guerra fratricida - foi incorporado como oficial por Bolívar, mas parece que não chegou a sair do país. Um retrato seu de Bolívar - junto a outras muitas miniaturas e quadros diversos (religiosos e flores) foi doado por um filho do pintor ao comerciante e naturalista inglês James Mudie Spence, para a Primeira Exibição de Belas Artes ocorrida no Café del Ávila, na Caracas de 1872. A miniatura de Bolívar era uma imagem "ao natural" assinada por "P. Malcampo, um de seus oficiais".14 Lamentavelmente, quando Spence publica o livro de suas andanças pelo país, Peace and war in the land of Bolívar (1878), a imagem que inclui na página de rosto corresponde ao retrato de Espinosa realizado em $I^{\circ}$. de agosto de 1828 em Bogotá. Dói saber que toda a coleção de Malcampo, de meio milhão de aquarelas, óleos, desenhos e fotografias venezuelanas deve ter desaparecido durante a segunda guerra mundial.

Mencionamos outros dois pintores mais, ambos discípulos de Antonio José Landaeta, um de regular formação e outro muito reconhecido como retratista em seu tempo. Referimos-nos, em primeiro lugar a José Hilarión Ibarra, quem deixa nas mãos de Maria Antonia Bolívar de Clemente, uma imagem eqüestre do Libertador, talvez a primeira na América, excetuando a escultura de madeira conservada por Boulton e de possível origem equatoriana, cerca de 1823 , também em miniatura. Ignora-se a data de execução deste Bolívar eqüestre venezuelano, em formato muito pequeno, quase uma figura de brinquedo e realizada com um estilo um pouco ingênuo, mas que sem dúvida é produto do impacto da última visita de Bolívar a Caracas, em 1827. Não se descarta que tenha sido inspirado na litografia do inglês de S. W. Reynold (I826), que parte por sua vez do quadro de David sobre Napoleão cruzando os Alpes. ${ }^{15}$

O segundo pintor, Juan Lovera, nascido em Caracas em 1776 e falecido na mesma cidade em I84I, foi o mais celebrado retratista de nossa primeira metade do século XIX. Coube a ele emigrar até o oriente, em 1814, junto com Bolívar e o resto da população caraquenha, e se radicou no Caribe até 1820. A ele se deve os primeiros quadros históricos de nossas efemérides fundacionais: 0 túmulo de 19 de abril de 1810 (I835) e A assinatura do Ato da Independência de 5 de julho de I8II (I838), ambas as datas decretadas então como dias de festas pátrias pelo governo de Páez. É muito
Cf. Enciclopedia del arte en América. Tomo 5, Argentina: Bibliográfica Omeba; 1969 e Diccionario Biográfico... (ob.cit.), tomo 2 .

Cf. "Inventário de obras exibidas na exposição do Café del Ávila, 1872”, em ESTEVA-GRILLET, Roldán. Fuentes documentales y críticos a las artes plásticas venezoelanas: siglo XIX e XX. Caracas: Conselho de Desenvolvimento Científico e Humanístico, Universidade Central da Venezuela; 200I, vol. I, pp. 254-279.

Cf. GONZÁlEZ ARNAL, María Antonia. "IBARRA, José Hilarión", no Diccionário biográfico...(ob. cit) Tomo I. 
"Celebração do triunfo de Carabobo e do Onomástico do Libertador", em Gazeta de Caracas, 8 de novembro de I82I; agora em ESTEVE-GRILLET, Roldán. Fuentes documentales $y$ críticas...(ob. cit.) Vol. I, p. 89.

Atas, Conselho Municipal, Arquivos Capitulares, tomo II, folha 4I; em DUARTE, Carlos F. Juan Lovera, el pintor de los próceres. Caracas: Edit. Arte; 1985, p.Il6.

Ibidem, p. I34.

Sir KER PORTER, Robert. Diario de un diplomático británico en Venezuela. 1825-1842. (tradução de Teodosio Leal e prólogo de Malcolm Deas) Caracas: Fundação Polar; 1997, p. 150. possível que, em I82I, com os festejos pelo triunfo de Carabobo, que coincidem com o dia do santo do Libertador, 28 de outubro, tenha sido o autor de um painel, colocado na estrada da capela da Universidade, na qual se figurava

\section{[...] um robusto e musculoso Hércules, e a Minerva adornada de todas as graças na atitude mais própria, colocando sobre a coluna da imortalidade o busto do grande Bolívar, cujo ato participava o gênio simbólico da Colômbia em um gesto de júbilo e satisfação, que ocupava a parte superior do quadro tendo em suas mãos as correntes rompidas, e na outra, o pavilhão da independência pendente do mastro que sustentava o gorro da liberdade, significando assim que a sabedoria e o valor de Herói se deve a elevação da Colômbia a alta categoria que goza, imortalizarão seu nome e a memória de suas eminentes qualidades. Na parte inferior se lia a seguinte epígrafe: Honra e Glória ao Libertador da Pátria. ${ }^{16}$}

Segundo Carlos F. Duarte, melhor estudioso de Lovera, a municipalidade pagou ao pintor 30 pesos pela pintura e demais custos do painel utilizado na celebração da Vitória de Carabobo, na Sala Municipal. ${ }^{17}$ No entanto, ganha crédito uma informação apresentada por Manuel Landaeta Rosales em 1906, segundo a qual Lovera teria feito um retrato de Bolívar no ano de 1827 e que a conservara por muitos anos o Sr. Juan Félix González. ${ }^{18}$ Não fica descartado que esse retrato possa ser similar aquele presenteado por Lovera ao artista norte-americano John Neagle, em 1835, hoje propriedade da Sociedade Histórica da Pensilvânia, pois nele Duarte descobre uma filiação com o de Gil de Castro, em Caracas desde 1826.

Não seria o único pintor de época a se inspirar nesse famoso retrato. Vivia em Caracas Sir Robert Ker Porter (Durham, 1777 - Rússia, 1842), diplomático britânico e pintor formado na real Academia de Londres; muito amigo de Páez, de sua prolongada permanência no país deixou o famoso Caraca's Diary. ${ }^{19}$ Neste Diário revela que Maria Antonia Bolívar, a irmã mais velha do Libertador, havia permitido fazer um desenho do retrato que ela acabava de receber do Peru em 1826. O copiou para seu próprio conhecimento e para enviá-lo a duas irmãs na Inglaterra, uma delas romancista e muito interessada em Bolívar. Tais desenhos não foram localizados, segundo Boulton. $O$ único que se conserva é a aquarela que fez do general Páez de uniforme de general-em-chefe e com chapéu emplumado.

Ficaria por explicar de quem foi o desenho que o inglês William Walton facilitou ao artista M.N. Bate, em Londres, para preparar a primeira lâmina de Bolívar. Inclinamonos a pensar que pode ter sido feito por um oficial britânico em Angostura, dos que Walton servia como fiador de viagem, em cujo retorno the havia entregue o desenho. 
Para maio de 1819, Bolívar recebia as primeiras provas da imagem, em setembro a litografia já estava em Trinidad, segundo Zea.

Em resumo, caso Boulton tenha razão, nenhum de nossos pintores, nem sequer o único estrangeiro com formação acadêmica, teve a oportunidade de pintar Bolívar nas tantas ocasiões em que passou por Caracas, apesar de ter nascido e vivido nela sua infância e primeira juventude. A guerra o levou pelo Caribe, pela atual Colômbia, o Equador e até o Peru, foi nesses países onde a produção de retratos se deu com maior profusão e onde alguns pintores tiveram a sorte de captar sua efígie pessoalmente.

\section{A fábrica política de imagens}

Abstraindo das gravuras ou litografias que constituíram a principal via de difusão na Europa da imagem de Bolívar desde 1819, e as obras escultóricas ou relevos que se originaram posteriormente a sua morte em 1830, na América Hispânica a efígie de Bolívar circulou através da pintura, basicamente em dois formatos: a miniatura sobre marfim de caráter privado e o retrato sobre lenço de caráter público. Não negamos que chegaram as estampas européias, só dois casos inspirados em obras americanas (Bate, 1819; Ch. Turner, 1827), resulta evidente que, para a época, a reprodução litográfica

O não havia se desenvolvido ainda na América e dependíamos das edições estrangeiras. Basta assinalar que no México em 1826 não se conhecia o rosto de Bolívar; uma dama nobre aficionada pela pintura conseguiu, depois de muito pedir, que um europeu recém chegado Ihe emprestasse por poucos dias uma gravura (a de Bate de 1819) para satisfazer o íntimo desejo de representar a Bolívar e enviar-lhe o retrato como signo de admiração. ${ }^{20}$

O costume na época, no caso de distanciar-se, era presentear as amizades ou aos familiares, ou aos amantes, o próprio retrato em miniatura, quando não uma mecha dos próprios cabelos. Bolívar o fez em suas duas primeiras estadias na Europa: em 1800 presenteou sua futura esposa, a madrilenha Maria Teresa de Rodrigues del Toro, com uma miniatura (fig. I), e já viúvo, presenteou com outra miniatura sua amiga e amante, Fanny Du Villars, antes de seu segundo regresso a Venezuela em 1806 (fig. 2). Já envolvido com

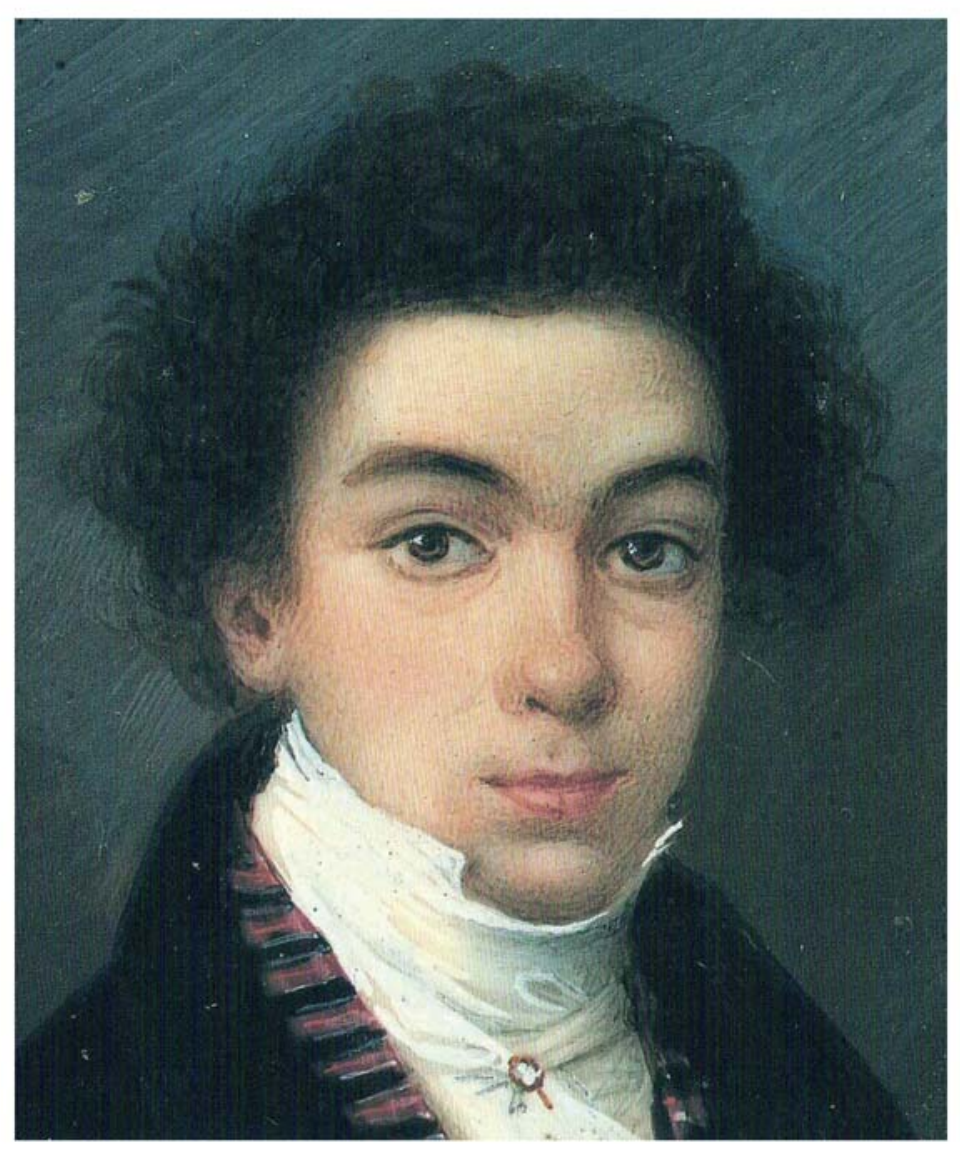


ט

A anedota é contada pelo pintor José Maria Espinosa, que acompanhava o soldado. Cf. Memorias de un abanderado... (1876), ob. cit, pp. 28-30. as lidas bélicas, estendeu $\circ$ gesto a pessoas que Ihe foram afetuosas ou que the ajudaram em algo. Por exemplo, em 1816 presenteou uma miniatura ao general Ignácio Marion, em agradecimento a sua hospedagem no porto de Los Coyos, Haiti, e por ter tê-lo apresentado ao presidente Alejandro Petion, por quem será entrevistado, em Porto Príncipe, na procura de auxilio financeiro; ou ao general San Martin, 1822, ao despedir-se em Guayaquil, depois de acordar que seria o exército Libertador que assumiria a última campanha contra os monarquistas no Peru.

Já em tempos de guerra, a miniatura para Bolívar servia, pois, mais que um cartão de apresentação, como cartão de despedida, deixava com quem contraia alguma dívida afetiva. Andava sempre provido de miniaturas e quem a recebia a conservava como um presente especial, devido a fama alcançada pelo herói.

Mas tudo mudou com a batalha de Boyacá, colocado em fuga o vice-rei Sámano do Novo Reino de Granada, em 1819. A Bogotá, Bolívar quis chegar apressadamente, sem escolta, esteve a ponto de ser atacado por um soldado que, tomando-lhe como um desses godos derrotados, com a lança em riste Ihe deu a voz de Alto, quem vive!, ao que Bolívar respondeu seguindo seu caminho com um não seja o Sr. Bobo!. Não somente era o aspecto que carregava - o uniforme vermelho maltrapilho e cheio de manchas por toda parte, e a casaca grudada no corpo, pois não trazia camisa - , senão que sua imagem não correspondia com a idéia simples de um general-em-chefe, seus próprios traços físicos eram praticamente desconhecidos. ${ }^{21}$

Disse Espinosa que a notícia de sua repentina presença encheu de extraordinário júbilo a toda população. Assim, se ordenaram os festejos, homenagens e reconhecimentos que Bolívar receberá por primeira vez e daqueles que irá aprender, entre outras coisas, que a tradição romana das entradas triunfais seguia mais vigente do que nunca e já não era privilégio dos vicereis; a outra lição era que o povo devia venerar seu Libertador, ainda que não estivesse presente, através de sua efígie multiplicada. Inaugurava-se o culto a personalidade como símbolo da pátria.

Fig. 2 
Em 9 de setembro de 1819 é decretado que

\begin{abstract}
Abaixo do dossel do Cabido da Cidade será colocado um quadro emblemático em que se reconhecerá a liberdade sustentada pelo braço do General Bolívar, e a seus lados estarão representados os três senhores generais de divisão (Anzoátegui, Santander e Soublette). ${ }^{22}$
\end{abstract}

O desfile e as homenagens se realizam no dia 18 do mesmo mês, quer dizer, o pintor escolhido contará apenas com dez dias para executar seu trabalho. Será Pedro José Figueroa, quem antes apagou uma imagem do rei Fernando VII, encarregada por um juiz, com a desculpa da anarquia que reinava e por temor a alguma desgraça. Para o quadro de Bolívar usa outra tela com um retrato já iniciado, representando nada menos que a Pablo Morilo, Comandante do exército Expedicionário de Costa Firme e Capitão General das províncias de Venezuela desde 1815.

Neste retrato de Bolívar, Boulton quis ver uma filiação com a gravura de Bate, só porque o giro da cabeça é para a direita e porque se inclui a alegoria da América. No entanto, o giro a direita pede a que Bolívar abrace a alegoria da América (e não da Liberdade como o prescrevia o decreto) que está a sua direita. Mas a própria alegoria de Bate é muito distinta: uma indígena semi-desnuda, que carrega uma lança com o gorro frígio. A alegoria da América não é inventada por Bate, já é conhecida na época: representa-se o continente com um jacaré, uma indígena adornada com um arco, aljava de flechas, saia e penteado com plumas em uma paisagem tropical. Já, a América que desenhou Figueroa - com uma bananeira a suas costas, um jacaré e uma cornucópia muda quanto à vestimenta e os atributos: sendo ele ainda um pintor de igreja, apela a iconografia que the resultava mais familiar. Por isso sua América aparece vestida a romana, como uma Magdalena antes do arrependimento, adornada com jóias, se bem que penteada com plumas, mas nada de gorro frígio. Não nos ocupamos da opinião, atendendo ao observado por Alberto Urdaneta, para quem Figueroa não copiava do natural, trabalhava muito de memória. ${ }^{23}$

Tal como conclui Bolton: Igual aos monarcas espanhóis, foi entronizado Bolívar. ${ }^{24} \mathrm{E}, \mathrm{a}$ semelhança dos tempos coloniais com a efígie do rei, agora o herói patriótico deve multiplicar-se para que esteja presente nas salas do poder e, eventualmente, para tirá-lo a desfilar. Também se corre o risco de que, como acontecia com os retratos dos rei, seja destruído por razões de animosidade política. O certo é que antes de Bolívar regressar a Angostura, as margens do Orinoco, onde deixou instalado um novo Congresso e pronunciou um transcendente discurso, pede-lhe Santander, desde Pamplona, em 8 de novembro de 1819, que envie um retrato seu a Guayana. ${ }^{25}$ Em Angostura a questão foi levada muito a sério, aplicando em seguida o exemplo de Bogotá, de entronizar também a Bolívar. Assim,
Gaceta extraordinária de Bogotá, 17 de outubro de 1819 , reproduzida no El Correo del Orinoco, no. 49, tomo III; em BOULTON, Alfredo. Los retratos... (op. cit.), p. 56.

URDANETA, Alberto. Papel periódico llustrado, Nos. 46 a 48, ano II, 0. 422, em ibidem, p. 57.

24 Ibidem, p.56.

LECUNA, Vicente. Cartas del Libertador, II, p. 15, em ibídem, p. 156. 
Correo del Orinoco, №. 49, tomo III; em ibidem, p. 156.

Idem.

Arquivo de Santander, Bogotá, Academia da História, Bogotá, 1945; em ibidem, p.157.

Libramientos del año de 182l, Arquivo anexo à Biblioteca Nacional, fundo incorporado ao Arquivo Nacional, folhas 81, 167, 245, 494; em ibidem, pp. I56-156.

SOT0, Francisco. Memórias; em ibidem, p.l64.
Soberano Congresso desejando dar ao Chefe e ao Exército Libertador de Cundinamarca um testemunho de reconhecimento Nacional; veio decretar, e decreta o seguinte: [...] $2^{\circ}$. Seu retrato será colocado sob o Trono do Congresso, com esta inscrição em letra de ouro: Bolívar, Libertador da Colômbia, Pai da Pátria, terror do despotismo. E mais abaixo em pequenos caracteres: "Decreto do Congresso em Angostura de 6 de janeiro de 1820". [...]. ${ }^{26}$

Na mesma Caracas, com o triunfo de Carabobo, também se pode exibir um retrato do ilustre Libertador [que] estava colocado na frente da primeira sala com a mesma inscrição que o soberano Congresso decretou para o que deve se configurar nas galerias do Senado. ${ }^{27}$

A lição é assimilada rapidamente pelo futuro Marechal de Ayacucho, Antonio José de Sucre, ao escrever a Santander de Cascajal (perto de Guayaquil), em 2 de abril de I82I, o seguinte: peço que o Sr. me mande dois retratos grandes do Presidente para Guayaquil e Quito porque o Sr. sabe o quanto influi nas pessoas ter uma idéia do chefe que as governa e mais quando desfruta de uma celebridade como Bolívar. ${ }^{28}$

Daí em diante será comum, em todo território liberado, encomendar um retrato de Bolívar para as autoridades, havendo que apelar às imagens de origem européia que circulavam. Em nosso país não nos consta que os pintores tenham se beneficiado especialmente deste comércio, que teve que esperar até o triunfo de Carabobo e, sobretudo, até a última visita de Bolívar a Caracas. Mas sendo Páez o chefe máximo, não se deve estranhar que fossem seus próprios retratos os que abundavam, mais ainda quando este se fez porta-voz, desde 1825, dos ressentimentos caraquenhos e valencianos por não ser a capital da nova república.

De Bogotá sabemos, por certo, que o não muito talentoso pintor Figueroa tirou muito proveito realizando retratos, já sem o caráter alegórico do primeiro e talvez mais apegado aos traços fisionômicos da pessoa, no entender de seu próprio juízo. Com efeito, para o ano de 1821, em 19 de fevereiro lhe pagam 112 pesos por várias pinturas ordenadas pelo Libertador, e em 5 de maio outros 200 pesos por vários outros retratos; em 22 de agosto lhe pagam 40 pesos e logo, em 2 de setembro outros 50, por dois retratos que se colocarão, segundo decreto de 20 de julho do Congresso Geral da republica da Colômbia, em um lugar distinguido nos salões do Senado e Câmera de representações. ${ }^{29}$

Em 1829 alguns destes retratos colombianos sofrerão a fúria de uma multidão revoltada anti-bolivariana, que entrará na Corte Suprema de Justiça e os fará em pedaços, a ponta de golpes e baionetaços, bradando: Viva a liberdade, morra o tirano! Tanto que em I830, renunciando Bolívar definitivamente ao poder, outro retrato de Bolívar devia ser conduzido, por ordem do Intendente, em volta da praça em uma das tardes de touros por uns militares e alguns membros da municipalidade. ${ }^{30}$ 
Estas manifestações de iconoclastia ou iconodulia também ocorreram na Venezuela. De iconodulia é bom exemplo o ocorrido em 15 de julho de 1828, particularmente em Caracas, ao se conhecer a dissolução da Convenção de Ocaña, que dará origem a última ditadura de Bolívar. Não podia ser outro senão o retrato mais prestigiado, o conservado por sua irmã Maria Antonia e exibido, a janelas abertas, permanentemente em sua sala principal. Assim conta Maria Antonia Bolívar em carta a seu célebre irmão Simon:

\section{[...] Ontem a noite houve uma grande festividade na praça com teu retrato e foi numeroso o ocorrido. O retrato foi e veio em procissão com música, todo povo e militares repetiam contínuos vivas e aclamações e pela manhã, agradecimentos com salva de Artilharia, enfim, o dia esteve muito divertido, pois até aqueles antigos gigantes [usados nas festas do Corpus] saíram pelas ruas [...].}

O tio Esteban Palácios não fica lacônico em sua versão, dada em carta de 21 de julho:

\begin{abstract}
[...] seguiu a tudo isso os festejos públicos de costume, como Igreja, Tropa e Povo, que estiveram bons, atendida a prontidão com que tudo foi feito.[...] e voltando aos festejos públicos, não devo omitir dizer-te que na noite se trouxe de Maria Antonia teu retrato em triunfo, acompanhado de tropa, muitos oficiais com tochas acesas e entre eles o cônsul da Inglaterra, e o povo que o acompanhava. Foi recebido com salva de artilharia e colocado em um pavilhão destinado ao impacto, em seguida canções e música, de maneira que tudo esteve bem e imponente, de sorte que os militares saíram de suas casas $\left[\ldots . .{ }^{31}\right.$
\end{abstract}

Como pano de fundo para as iconoclastias cabe recordar que a nova República da Venezuela - ao separar-se da Colômbia em 1830 - exigia entre outras condições, para retomar as relações entre os países, que primeiro fosse expulso o Libertador desse território. Bem podemos imaginar quantos esconderiam os retratos de Bolívar ou francamente colaborariam com sua destruição, agora por razões adversas a admiração que antes esbanjavam.

No Equador foi um pintor indígena cuencano, Gaspar Zangurina, chamado o Llukui ("canhoto"), quem melhor aproveitou a presença de Bolívar para o exercício de sua profissão; executou esse retrato "ao vôo", segundo a expressão de frei José Maria Vargas. Ganhou com isto, com justiça, uma pensão vitalícia de trinta pesos mensais e a condição de diretor de uma escola de Artes e Ofícios a partir de outubro do mesmo ano. Muitos retratos pintados sobre metal, com um Bolívar de aspecto tosco e rude, se

(1)




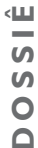

General San Martin na carta de 19 de abril de 1827 ao general Millar, em ibidem, p. 158.

"Relação das festas com que se celebrou na cidade de Trujillo a vitória de junín", em Gaceta del Gobierno, №. 36, tomo 6, de sábado, 21 de agosto de 1824; em ibidem, p. 159.

Gabriel René Moreno; em Encina, Francisco A. Bolivar. Emanación de Quito y alto y Bajo Peru. Santiago, Chile: Nascimento; 1954; em ibídem, p.159.

Ibidem, p 78. atribuem a sua iniciativa; inclusive $\circ$ modelo, fundido com 0 de Figueroa "das três medalhas", chegou a influenciar nos primeiros retratos do peruano Gil de Castro em 1823, antes de ter a frente o personagem em 1825.

De quem haverá sido a miniatura presenteada por Bolívar, como uma memória a sua sincera amizade, ao general José de San Martin, em 28 de julho de 1822, quando este embarcou em Guayaquil? ${ }^{32}$ Ignoramos, tão pouco Boulton o explicou. Talvez seja de Zangurina, a menos que Bolívar a trouxera da Colômbia, ainda que se saiba que Figueroa não era miniaturista e Espinosa ainda não havia se dado a conhecer.

No Peru a coroação se inicia com a batalha de Junín, em 1824. Na cidade de Trujillo se festeja com um banquete republicano, inclusive com baile na casa do presidente da Corte Superior de Justiça. A presença de Bolívar se fazia viva com seu retrato sob o dossel. ${ }^{33}$ Mas, será mais festejado com o triunfo de Ayacucho, estando a mando do exército patriota 0 venezuelano Antonio José de Sucre. Em Lima se festejou nos salões da Universidade, com Bolívar sob o dossel como de costume, e também em Buenos Aires, onde tiraram em procissão o retrato de Bolivar pelas ruas com luzes acesas em noite de pampeano. ${ }^{34}$

Como ocorreria na Venezuela, Colômbia e Equador, também no Peru e logo na nova república da Bolívia, emitiram-se decretos ordenando a colocação de retratos de Bolívar nas salas de reuniões dos poderes do Estado.

Várias homenagens se tributaram ao Libertador pelo triunfo de Ayacucho: emissão de medalhas comemorativas, prêmio em dinheiro (um milhão de pesos para o exército e outro milhão para ele mesmo, que certamente não cobrou, mas que logo o fará Antonio Leocadio Guzmán em nome da família), uma espada adornada com materiais e pedras preciosas, a condecoração do Sol do Peru incluindo o estandarte de Pizarro, uma relíquia de tempos de conquista. Interessa reter o seguinte e com isto concluímos esta parte: a Municipalidade manda o artista, cosmógrafo e engenheiro militar, o mulato José de Gil de Castro, desenhar um uniforme de gala, similar a Bolívar e Sucre, e como complemento o mesmo artista se encarrega de seus respectivos retratos. De Bolívar já dissemos o fundamental, mas quando saem do país as duas versões, a de Wilson e a de Maria Antonia, a municipalidade de Lima se vê necessitada a encomendar um novo retrato a Pablo Rojas, em quem se descobre a influência tanto de Gil como do Anônimo peruano de 1825 (atualmente na Assembléia Nacional venezuelana). Gil voltará a pintar Bolívar, depois da morte do ilustre. E também apelará ao modelo estabelecido pelo Anônimo de 25, que se difunde pelo Equador com Rafael Salas e o austríaco Francis Martin Drexel. O retrato feito por este autor anônimo é, segundo Boulton, de grande conhecimento plástico e de primeiríssima qualidade. ${ }^{35}$

\section{Da gloria ao desprezo}

Do ano de 1828, ano crucial de prestígio do Libertador, se conserva essa imagem de Bolívar, de uniforme militar, com o corpo ladeado para a esquerda, com os braços 
cruzados e o olhar oblíquo, realizada por José Maria Espinosa no palácio de San Carlos em Bogotá. É a imagem que Bolívar quer projetar para uma época em que odeia governar, pois isso significa estar longe do campo de batalha e ter que ganhar a pulso diplomático o apoio de seus adversários.

Bolívar deve atender urgências militares, rebeliões no Equador, e estando em campanha novamente um engenheiro militar, Pio Domingo del Castillo, aproveita para fazer-lhe uma miniatura, onde o personagem brilha rejuvenescido. A decadência física, os estragos da doença, o cansaço e falta de ânimo, a flacidez das carnes, a expressão fugidia e desfigurada, seu cabelo já escasso e grisalho, sua ausência total de esperanças, salvo a de sair para longe, seu tremendo aborrecimento por governar (disse Bolívar que o mecanismo de governo me cansa extraordinariamente): tudo isso somente é captado pelos desenhos que entre o ano de 1828 e 1830 o fazem Espinosa para si, inclusive em posturas tão naturais, como desprevenidas, de perfil com chapéu jipijapa equatoriano, de civil com o olhar perdido, e a mais patética de todas, aquele rosto com poucos traços que sintetizam o fim de uma carreira, a desilusão absoluta. Se por um lado o mesmo Espinosa reconhecia que do primeiro retrato, para o qual posou expressamente - Libertador em San Carlos, havia tirado um grande proveito pois o copiou e vendeu muitas vezes ${ }^{36}$, por outro lado guardou para si essas imagens íntimas, que só nos chegaram posteriormente graças a vontade de Boulton por descobrir o homem por traz da máscara palaciana dos retratos oficiais. Estas são as palavras:

É talvez o mais dramático retrato jamais feito de Bolívar [...] Os escassos traços, realizados com vigor e rapidez magistrais, refletem com vivíssimo realismo o fatigado semblante. Nesta enfraquecida fisionomia se acumulam com ênfase, as menores e as maiores experiências da sensibilidade de um homem que havia alcançada elevada exaltação, e que desfrutou e gozou com requinte a agradável euforia do gênio e da glória [...] estas obras respaldam o artista colombiano como um excelente desenhista de retratos, posto que, com segura economia de traços conseguiu transmitir o que em suas pinturas e miniaturas mais elaboradas não alcançou captar. [...] Neles se apresenta um Bolívar de 46 anos que não estávamos acostumados a ver. Enfraquecido, envelhecido e em plena decadência física. ${ }^{37}$

Mais dois artistas aparecem nestes anos finais, dois europeus que a sua maneira engendraram modelos que influíram em versões posteriores. $O$ primeiro foi o médico e professor de fisiologia Francois Desirée Roulin, muito bem preparado no desenho e na miniatura, tanto que viveu uns quatro anos deste ofício, entre 1824 e 1828. Realizará um

Em suas Memorias revela Espinosa: Pela cópia de Bolivar, que conservo em meu poder, fiz depois muitas outras para estrangeiros e conterrâneos; 0 último foi a óleo, de corpo inteiro e tamanho natural. Este último óleo encontra-se hoje no Palácio de Miraflores.

BOULTON, Alfredo. El rostro de Bolivar. Caracas: Ed. Macanao; 1982, p.64. 


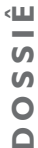

Ibidem, p. 44.0 desenho original não existe, somente 0 buril recolhido por Alberto Urdaneta em I88I.

BOULTON, Alfredo. Los retratos de Bolivar, (ob.cit.), p.89.

BOULTON, Alfredo. El arquétipo iconográfico de Bolívar. Caracas: Ed. Macanao; 1984.

Em USLAR PIETRI, Arturo. "Bolívar e as mulheres", em Bolivar hoy. Caracas, Monte Ávila Editores, p. 123. Outra mulher com quem Bolivar teve uma aventura amorosa, nos seus 19 anos, antes de casar-se, mas estando já comprometido, seria Teresa Laisnay, casada com um coronel peruano, Mariano Tristan. Como romancista que era, Uslar Pietri gostou de pensar na possibilidade de que a menina que teve logo Teresa, a famosa Flora Tristan, fosse produto desse amor juvenil, o que faria de Bolivar 0 avô de Paul Gauguin...
Bolívar de perfil, extremamente idealizado, mas obedecendo as características físicas mais permanentes de sua fisionomia, como poderia ser seu queixo proeminente, seu nariz reto, seus olhos fundos, seu rosto amplo, seus cabelos penteados au coup du vent (FIG. 4). Para Boulton o magnífico perfil de Roulin se caracteriza por essa mesma impressão de isolamento, de nostalgia e de retraimento que nos transmitem os finos traços deste buril e que envolvem a Bolivar num repousado gesto de paz. ${ }^{38} \mathrm{Em}$ relação ao pintor disse: Foi de todos os retratistas do Libertador, o de maior cultura e formação artística, tinha disposição natural de bom pintor. ${ }^{39}$

Em seu regresso ao país natal, em 1829, manda fazer uma miniatura a partir de seu perfil, mas com uniforme militar.

O perfil neoclássico de Roulin teve

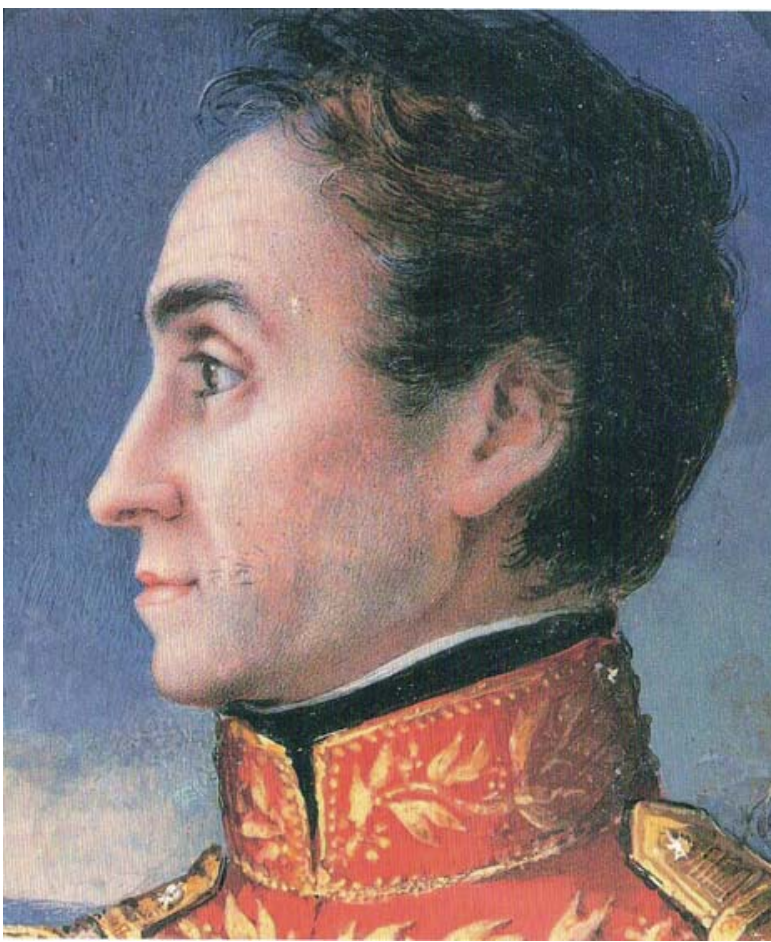

Fig. 3 igualmente uma grande influência no arquétipo do Libertador, vale dizer, sobre sua imagem póstuma levada ao campo da escultura pelo italiano Pietro Tenerani (I83I, I836, I846, I852), nos relevos e nas medalhas pelo francês Davis d’Angers (1832), na litografia de Fernández-Tavernier (I84I), na estatuária do italiano Adamo Tadolini (1859), na moeda nacional pelo gravador francês Albert Dessiré Barre $(\mathrm{I} 88 \mathrm{I}) .{ }^{40}$

O outro artista será o romano Antonio Meucci, casado com uma pintora espanhola com quem trabalhou nos Estados Unidos, inclusive como decorador de teatro, e que chegou a Colômbia em 1830, de Kingston, Jamaica. Meucci, contrário ao realizado por Espinosa, mas competindo claramente com ele, consegue que Bolívar pose para várias miniaturas, basicamente quatro, presentes para diversas de suas amizades. Uma delas, de intensa repercussão em seus afetos e lembranças da época brilhante e desinibida de Paris, estando já viúvo. Fazia vários anos, encontrando-se no ápice de sua glória, em 1826, havia recebido uma carta de sua antiga amiga e amante francesa, Fanny du Villars:

Dedico esta mensagem para nós dois. Hoje faz 21 anos [...] que o Sr. deixou Paris e que me deu o Sr. um anel que leva essa mesma data, 6 de abril, mas ao invés de 1826, I805, quando o fato ocorreu. 
Este anel tem sempre me acompanhado trazendo-me à memória a grata recordação de uma amizade que o Sr. me assegurou que só terminaria com seu último suspiro, naquele momento esse sentimento me pareceu débil. Lembra oSr., minhas lágrimas vertidas, meus suplícios para impedir-lhe de partir? Tive e tenho ainda a confiança de crer que o Sr. me amou sinceramente e que, em seus triunfos como nos momentos em que corria o Sr. algum perigo, pensou que Fanny dirigiaIhe seus pensamentos [...] Conserve o Sr. meu retrato, ele será mais feliz que eu, porque ao enviar-lhe minha imagem, não tenho o poder de emprestar minha alma a minha fisionomia: se o tivesse, talvez, esqueceria meus anos ${ }^{41}$.

No fundo, a carta era um pedido de auxilio econômico e ia acompanhada com duas miniaturas, a dela e a de seu filho Gustave. Bolívar tardará quatro anos em responder e o fará com uma miniatura sobre marfim que, apesar de revelar sua idade, não ○ faz igual com seu estado de ânimo e desgaste físico. Soube o artista Meucci, dentro de suas limitações, interpretar o gesto galante de Bolívar e o mostrar no melhor estado, para seu orgulho de homem romântico (fig. 5). Disse Boulton: esta imagem simboliza o último gesto sentimental e romântico do grande homem. ${ }^{42}$

De Meucci pouco se sabe mais além de sua itinerância americana. Da Colômbia viajou em 1833 ao Peru; ali lhe encontrará Belford Wilson, o antigo ajudante, que lhe adquire uma miniatura de Bolívar, que havia sido de O'Leary e que havia ficado inacabada. Não permitiu que a concluísse e assim a legou aos próprios filhos com uma carta explicativa. Belford regressou em 1843 a Bolívia para doar o famoso quadro de Gil de Castro que Bolívar havia presenteado a seu pai em 1825. Até 1847 se tem conhecimento da permanência de Meucci em Lima. Com este pintor, desconhecido para a Itália, conclui-se a série de retratistas europeus e americanos que deixaram para a posteridade uma imagem do Libertador. ${ }^{43}$

\section{A armadilha bolivariana}

O bolivarianismo não foi um fenômeno do passado venezuelano ou americano, conectado com exclusividade às lutas independentistas. Ao longo do século os diversos países afetados pelo seu gênio militar e político, tiveram a

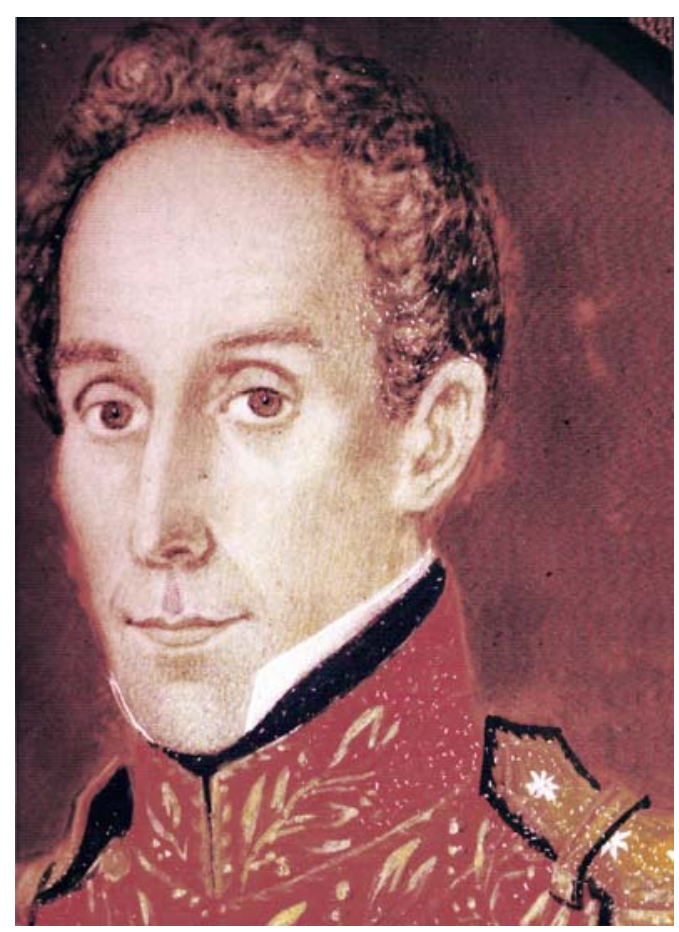

Fig. 3
BOULTON, Alfredo. Los retratos... (ob. cit.), p. 104.

Em nossa relação, se nota que não nos ocupamos com os detalhes das gravuras e litografias européias, também estudadas e colecionadas por Boulton. Da estatuária póstuma se ocupou extensamente PINEDA, Rafael. Las Estatuas de Simon Bolivar en el mundo. (prólogo do presidente Rafael Caldera) Caracas: Centro Simon Bolivar C. A.; 1998 (2ª Ed.). 


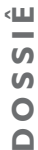

Cf. PINO ITURRIETA Elías. El divino Bolívar. Ensayo sobre una religión republicana. Madrid: Los libros de Catarata; 2003 (2da. ed.), pp.28-33. Cf. Também SALAS DE LECUNA, Yolanda. Bolivar y la historia en la consciencia popular. Caracas: Instituto de Altos Estudos de América Latina, Universidade Simón Bolívar; 1987. necessidade de safar-se de sua influência exemplar, em parte por não se compreender sua visão integradora, tão em dívida com a mesma de Miranda.

O culto a Bolívar irá se reconstituindo em nosso país, uma vez estancado o sangue das feridas, a partir de uma expatriação dos restos do herói, sepultados em Santa Marta. A iniciativa surgida originalmente do setor opositor ao governo de Páez, liderado por Tomás Lander e Antonio Leocadio Guzmán (o mesmo que havia viajado até o Peru para reclamar em nome da família o milhão de pesos que Bolívar não quis para si), é rapidamente assimilada como política de estado pelo mesmo Páez. Assim, se decretam em 1842 as Exéquias de Bolívar e se nomeiam comissões que se encarregam de dirigi-las de maneira que a reparação da falta constitua uma causa de reconciliação nacional.

O general Rafael Urdaneta se encarregará em Paris de adquirir todo o necessário para o ornamento da cidade, o carro fúnebre e o túmulo. $\bigcirc$ tribuno Fermín Toro será o cronista literário e Carmelo Fernández, o desenhista oficial. No entanto o retrato oficial para a ocasião será encomendado a um artista francês, o já mencionado Paulin Guerin, enquanto que o monumento estatuário, a Tenerani, segue o modelo realizado para a Praça de Bolívar de Bogotá. Tudo se regirá pela cerimônia que o rei Luis Felipe da França preparou para o regresso dos restos mortais de Napoleón Bonaparte.

Poderia se pensar que desde esta data o prestígio de Bolívar ficou restabelecido na consciência nacional. No entanto, popularmente, a admiração pelo grande homem nunca se enfraqueceu, tanto é assim que com facilidade, uma vez morto, podiam the pedir favores como um santo qualquer. Com efeito, está registrado que já em 1832, em São Fernando de Apure, uma procissão de súplica para que as águas do rio voltassem a seu curso normal, carrega um desenho da junta de 19 de Abril, outro de Miranda e finalmente um letreiro com as palavras de Bolívar ante o terremoto de 1812: Se a natureza se opõe. E, em 1836, em Guanare, se determinam umas honras fúnebres a Bolívar, seu retrato é levado em um andor e aos seus pés colocam frutos e instrumentos de lavoura, para atrair com 0 ato a bondade da natureza. Até mulheres choraram durante a cerimônia. ${ }^{44}$

Durante a hegemonia do general Antonio Guzmán Blanco, que governou direta ou indiretamente o país entre 1870 e 1888 , foram freqüentes as ocasiões para o estímulo deste culto oficial, que já tinha sua consistência popular nas crenças mágico-religiosas. A arte se prestou maravilhosamente para legitimar este novo sentimento nacionalista que escondia outro culto da personalidade, a do próprio Presidente. A comemoração do primeiro centenário do nascimento de Bolívar foi a grande desculpa para um excesso de iniciativas, a mais importante de todas foi a Exposição Nacional, onde se encontraram todos os artistas que haviam sido protegidos pelo regime, através do sistema de bolsa de estudo na Europa.

As principais obras de arte referidas aos acontecimentos da independência vêm daí. Martín Tovar e Tovar, Antonio Herrera Toro, Arturo Michelena, Cristóbal Rojas, 
Manuel Cruz, Juan Antonio Michelena entre os pintores; Rafael da Cova como único escultor; todos abordaram temas retirados da história da pátria, especialmente afetados pela recente publicação do primeiro romance literário épico, Venezuela Heróica, de Eduardo Blanco. Outras séries de marcos históricos são: a elevação da canção patriótica Glória ao bravo povo! à condição de Hino Nacional; a criação da unidade monetária, o Bolívar; a publicação das Memórias de O'Leary; a elevação da estátua eqüestre do Libertador na Praça de seu nome e a transferência dos restos de Bolívar ao Panteón Nacional; a doação do famoso retrato de Gil de Castro, por parte dos herdeiros de María Antonia Bolívar de Clemente, para ornamentar o Palácio Federal. ${ }^{45}$

Na primeira metade do século $X X$, se adquiriu por assinatura popular, a casa natal de Bolívar, que constava entre as múltiplas propriedades de Guzmán Blanco. O governo do general Juan Vicente Gómez encomendou ao pintor Tito Salas, a decoração com cenas da vida do herói, tanto de sua casa natal como a do Panteón. Ainda, na morte de Gómez, se recorrerá ao mesmo pintor para um Bolívar eqüestre que substituíra o retrato entronizado do ditador no Palácio de Miraflores.

A partir dos anos quarenta pode se dizer que tem início um resgate da figura de Bolívar ${ }^{46}$, que havia sido transformada pelos sucessivos líderes em uma espécie de totem autoritário, providencial, sobre-humano, uma antecipação do que o filósofo do regime gomecista, Laureano Vallenilla Lanz, denominara “o vigilante necessário”, em sua obra Cesarismo Democrático (1919). A mesma bandeira que ressuscitou um filho seu com a última ditadura militar (1948-1958), personalizada em Marcos Pérez Jiménez, com "O Ideal Nacional" e suas "Semanas da Pátria" e que parecera reciclar-se com a nova onda de bolivarianismo nacionalista e militarista que sofre nosso país na última década. Abster-nos-emos de qualquer comentário, mas haverá que tê-lo presente para se entender algumas jogadas do comércio da arte.

Dentro desta renovação de estudos bolivarianos é que entraria o grande aporte de Alfredo Boulton, desde a história da arte, com seu livro Os retratos de Bolívar, que hoje comemoramos seu cinqüentenário. Sem dúvida que a aparição de tantas revelações juntas estimulou a revalorização de um patrimônio histórico artístico herdado e conservado na indiferença, sem que ninguém, até o momento, o tivesse dedicado uma atenção preferencial como caminho para conhecer melhor ao homem que foi Bolívar. Só que, como há observado um de seus seguidores, o historiador e restaurador venezuelano, Carlos F. Duarte:

As obras ali reproduzidas receberam um valor inestimável, não só desde o ponto de vista histórico ou documental, senão econômico também. Desgraçadamente, o que por um lado vem a ser positivo para valorizar, apreciar e conservar estes testemunhos, também fomenta a ambição, o engano e a falsificação.

Cf. ESTEVA-GRILLET, Roldán. Guzmán Blanco y el arte venezolana. Caracas: Academia Nacional da História; 1986.

Verbi gratia: ARRÀIZ, Antonio. Culto bolivariano (1940); KEY AYALA, Santiago Vida ejemplar de Simón Bolivar (1942); TEJERA, Humberto. Bolívar, guía democrático de América (México, 1944); SALCEDO BASTARDO, José Luis. Visión y revisión de Bolívar (1957); MIJARES, Augusto O Libertador (1964); CARRERA DAMAS, Germán. El culto a Bolívar (1969); ACOSTA SAIGNES, Miguel. Acción y utopia del hombre de las dificultades (1977); USLAR PIETRI, Arturo. Bolivar hoy (I983); PINO ITURRIETA, Elías. O divino Bolívar (2003); CABAlLERO, Manuel. Por qué no son bolivariano (2006) 
DUARTE, Carlos F. "A falsa iconografia de Bolívar e Miranda. História de uma fraude", em Boletin de la Academia Nacional de la Historia, No. 334. Caracas: AbrilMaio-Junho de 200I, p. 263. Boulton havía falecido em 1995.

\section{8}

É tal a emoção de Boulton pelo achado desses novos retratos, que no ano seguinte publica um livro dando conta da novidade: Miranda, Bolivar y Sucre. Três estudos iconográficos. Caracas: Italgráfica; Caracas, 1959.
Desta maneira, a partir de 1956, quando apareceu o livro Os retratos de Bolivar, começaram a surgir quadros e miniaturas desconhecidas, algumas incontestavelmente autênticas, porém outras [foram] produto da falsificação, estimulada por antiquários desejosos para lucrar rapidamente, usando a boa fé dos aficionados e historiadores. Desta forma se aproveitou o interesse que suscitaram os descobrimentos expostos por Boulton, porém, ocorre que tristemente o mesmo Boulton foi vítima de suas próprias revelações. ${ }^{47}$

Aconteceu que Boulton entrou em contato com um cubano radicado em Nova York, especializado no comércio artístico particularmente de peças históricas como documentos, medalhas, miniaturas e em geral retratos e objetos que tivessem pertencido a algum de nossos nobres americanos do século XIX. Duarte conta em pormenores essas relações, através da correspondência consultada na Fundação John Boulton. O sistema utilizado pelo personagem de sempre, Manuel Bustillo, era simples: junto a peças autênticas oferecia outra de procedência incerta, a propósito da qual - no caso de solicitada informações mais precisas acerca de sua origem - se protegia diante das dificuldades de comunicação com o proprietário original.

No ano de 1958, sabendo que Boulton lamentava não haver conseguido imagens de Bolivar entre o ano de 1812 e 1819 , justamente de sua época mais tortuosa, quando procura auxílios econômicos para retomar a guerra e sofre com a reticência de seus companheiros a reconhecer novamente sua autoridade sucedidos seus fracassos, Bustillo revela um descobrimento assombroso: um retrato de Bolívar de quando havia estado no Haití, por ocasião de sua primeira entrevista com o presidente Alejandro Petion. O retrato, em pastel, de boa execução, sobre um papel sem dúvida antigo, trazia uma data equivocada (I8I5), o lugar de sua realização, Port au Prince, e a identificação do personagem em francês. A peça era de autor anônimo. Boulton mordeu a isca sem dizer nada e pagou seus dois mil dólares. Havendo acenado Boulton a possibilidade de conseguir algum retrato do revolucionário Francisco de Miranda, o hábil Bustillo, ao limite de dois meses, lhe revelou outro descobrimento, outro pastel, mas agora com a efígie de Miranda, de perfil. Outros dois mil dólares são desembolsados. Ambos os retratos eram acompanhados nas suas ofertas de negócio, com histórias de sua origem, mais ou menos aceitáveis, porém não comprováveis. E quando Boulton, como bom historiador, quer ter acesso à fonte direta ou comprovar por outras vias, se encontra com evasivas ou declarações de esforços esgotados, que pedem a busca de novas informações. ${ }^{48}$

Diante de tais êxitos de venda, ao final do ano de 1959, Bustillo publica um aviso, em uma revista de leilão, solicitando documentos, medalhas e miniaturas de interesse histórico. Apresenta-se a ele uma jovem italiana que, supostamente, teria lido mal o aviso, pois não se buscavam miniaturistas. $O$ certo é que a jovem, com muito boa 
preparação artística, com experiência em museus de Florência, passou a trabalhar para Bustillo na cópia de miniaturas. Seu nome: Marissa Viassone.

Neste mesmo ano Maury Bronsen adquire uma miniatura na casa de leilóes Parke Bernett Galleries Inc. Em 1965 é a vez de lvi de Suárez, que adquire outras três para doar ao Museu Nacional de Colômbia, em Bogotá; do mesmo lote em oferta, Maury Bronsen adquire uma a mais.

Com o tempo, o Museu Nacional de Colômbia publica um catálogo com suas miniaturas, e Marissa Viassone - então radicada na Alemanha - identifica "suas" miniaturas e redama sua autoria. Para maior evidencia envia ao Museu seus planos preparatórios com a quadrícula, e os presenteia uma miniatura. Em 1993, o novo catálogo do Museu Nacional reconhece a autoria de Viassone e relata sua trajetória de notável miniaturista. Nesse mesmo ano ingressa à Galeria de Arte Nacional de Venezuela uma miniatura, inspirada por Espinosa e adquirida no ano anterior por Axel Stein em Nova York. Havia sido certificada por Alfredo Boulton como autêntica.

Em 1999 Maury Bronsen decide doar sua coleção de antigüidades americanas (trinta e quatro peças) para a Universidade de Brown, Providence. A instituição solicita a Sotheby's a avaliação correspondente. Como existem seis miniaturas com personagens sul-americanos, se entra em contato com sua representante em Caracas, Axel Stein, quem consulta Carlos F. Duarte. $O$ parecer de ambos é negativo a partir de simples fotografias. Exigem ver os originais para pronunciar-se. Comparecem a um encontro nos Estados Unidos, para o qual também está convidada a diretora do Museu Nacional da Colômbia, a artista e investigadora de arte Beatriz González. Sobressai a história de Bustillo e Viassone, se estabelece contato e convida-se Viassone. Às seis miniaturas reconhece como suas, quatro de Bolívar e duas de Santander, e declara haver realizado umas cento e vinte no total, inclusive de personalidades norte-americanas. Aproveitando a ocasião expressa seu desagrado pelo uso que deram a sua obra.

De regresso a Venezuela, Duarte revisa a correspondência de Boulton e submete ao estudo minucioso os dois pastéis adquiridos em 1958 de Bustillo. Havia-lhe chamado a atenção, precisamente, por que uma das miniaturas de Viassone se correspondia com o pastel de Bolívar, mas com a imagem invertida. Apoiando-se em sua perícia como restaurador e em seus estudos sobre a história da vestimenta, denuncia a falsificação de ambos os pastéis, possivelmente atribuíveis a um mesmo autor. Descarta Viassone, que só realiza miniaturas a guache. E examina a miniatura da Galeria de Arte Nacional, que também considera falsa, no sentido de obra atual. ${ }^{49}$

Este caso, reconstruído tão impecavelmente por Duarte, perito restaurador, colecionista e historiador de arte, nos fez pensar em outros casos menos investigados. Apresentaremos somente um, com alguma ramificação: um retrato de Bolívar atribuído a Goya.

Consultado Duarte sobre o assunto, nos revela que o quadro foi adquirido em Gênova, por um norte-americano em um posto de estrada; apresentado a Duarte

49

As análises e razoamentos de Duarte não vêm ao caso resumir-los, só acrescentaremos que o citado artigo, em sua contundência, finaliza com 0 resumo da correspondência entre Bustillo e Boulton, onde fica evidenciado 0 manejo truculento da parte do comerciante, graças à confiança conquistada por parte do colecionista. 
Cf. CALZADILLA, Juan. Una colección de pintura en la Venezuela. Obras de arte en la colección Arnold Zingg. Bilbao: Ed. La Gran Enciclopedia Vasca; 1982.

"Um livro registra 0 achado: Obras desconhecidas de Goya na Venezuela", em El Universal, Caracas: 10 de março de 194.

0 caso está, nos dias que correm, nas mãos do Instituto de Patrimônio Cultural. para sua análise, o experto venezuelano indeferiu a antigüidade do quadro, pintado em estilo acadêmico sobre uma tela velha. Recomendou desfazer-se do mesmo, pois não teria maior valor. $O$ dono o vendeu a um antiquário caraquenho que, por sua vez o ofereceu em sua loja como um anônimo italiano. Assim o adquiriu um colecionista venezuelano, Diego Bosque García, que o mandou a enquadrar; é o mesmo colecionista que em 1968 adquirirá o retrato de Bolívar de corpo inteiro pintado por Espinosa em 1863. Posteriormente, ambos os retratos foram vendidos ao colecionista Arnold Zingg Aranguren, um reconhecido empresário interessado em arte colonial e hispano-americano. ${ }^{50}$

Começa, então, a atuar um suposto especialista em arte européia, de origem húngara, de nome Ralph Zoltan Medgessy, estabelecido em Toronto desde meados dos anos sessenta; defende uma tese bizarra a respeito de quadros de Goya: as microassinaturas que o pintor havia colocado para neutralizar as falsificações que já ocorriam em sua época. Estas micro-assinaturas não teriam uma localização especifica e poderiam variar em quantidade. $\bigcirc$ fundamento para suas afirmações as obtém Medgessy de um laboratório pessoal que se reduz a uma simples lupa e uma grande imaginação para "ver" micro-assinaturas em muitas e pequenas marquinhas deixadas pelo pincel ou mesmo pela craqueladura da capa pictórica. Pois bem, o citado especialista em arte européia foi contratado por Arnold Zingg e como produto de seu espalhafatoso método, pretende descobrir dezenove obras atribuídas a Goya, entre elas o mencionado Bolívar adquirido em Gênova e já na coleção Zingg.

Tendo como motivo a edição de um livro todo em cores, exibem-se oito dessas obras supostamente de Goya, no Ateneo de Caracas, somente no dia do lançamento, em 1994. ${ }^{51}$ A imagem de Bolívar é a única que exibiria uma só e modestíssima microassinatura, na ponta do nariz. Resulta fácil vincular este rosto com o último Espinosa, quem nos deixou suas marcas desde o ano de 1828 a 1830. E resulta que Goya morre em 1828. Não vale a pena discutir diante de semelhante farsa.

Da coleção Zingg saíram vários retratos de Bolívar: o de Espinosa de corpo inteiro foi adquirido para o Palácio de Miraflores, certificado por Boulton. Também uma cópia do Anônimo peruano de 1825, comprado pelos Estados Unidos, passou a Fundação Polar, previa certificação de Boulton em 1977. O original está na Assembléia Nacional. E agora este Bolívar, atribuído a Goya de maneira tão truculenta, está sendo ofertado para o governo nacional, declaradamente bolivariano. ${ }^{52}$

Se não fora por que em 1998, ano de eleições presidenciais, apareceu um artigo assinado por um tal Miguel Mosqueda Suárez, escritor e historiador venezuelano, donde se afirma desde o título: "Cinco rostos de Bolívar pintados por Francisco José Goya", toda esta operação não teria maior conseqüência.

Os rostos em questão são: a miniatura presenteada a sua esposa em Madrid, cerca de I800; a miniatura presenteada em Paris a Fanny du Villars em I805; o pastel do Haiti, 
de 1816 (hoje reconhecidamente falso); a miniatura realizada de perfil de Roulin, em Paris, cerca de 1829. Casualmente estas quatro obras pertencem a Fundação John Boulton e, segundo o autor, seguem sendo atribuídas a autor anônimo por que desde então não se haviam descoberto as assinaturas secretas de Goya. Conclui-se com o grande retrato de Bolívar, adquirido por Zinga em 1969 e a referência ao livro Goya in Venezuela.

Esperamos que desta vez a armadilha fracasse, para não nos desculparmos logo de boa fé.

\section{O último Bolívar}

Não poderíamos encerrar este artigo sem mencionar o último achado de Boulton, uma miniatura entre os papéis e condecorações de Guzmán Blanco, conservada em uma caixa forte alemã em Paris e que passou quase um século sem ganhar a curiosidade dos herdeiros. A proximidade do quinto centenário do descobrimento da América, em 1992, animou a Boulton a preparar um livro de luxo onde intentou demonstrar que a imagem havia sido feita a propósito da entrevista de Pablo Morillo e Simon Bolívar em Santa Ana de Trujillo, a mesma aldeia onde sete anos antes o venezuelano havia pronunciado o Decreto de Guerra a Morte. Em novembro de 1820, ambos os chefes militares acordaram um pacto e um tratado de regulamentação da guerra. Houve banquete e ambos os chefes militares compartilharam o mesmo quarto de dormir como signo de respeito e confiança.

A miniatura aparece assinada e datada, e também traz abreviado o lugar onde havia se realizado (fig. 3). Como se sabe que Morillo colaborou com dois desenhistas que tomariam anotações da entrevista e do banquete, para a realização de um monumento e sua divulgação em gravuras na Europa, nosso experto bolivariano se deixou levar pela emoção das mesmas cartas amistosas trocadas logo pelos dois chefes militares. $E$ assim apoiou a condição espanhola do pintor, um tal J. Yáñez, em I82I, em Gyt. Esta parte não

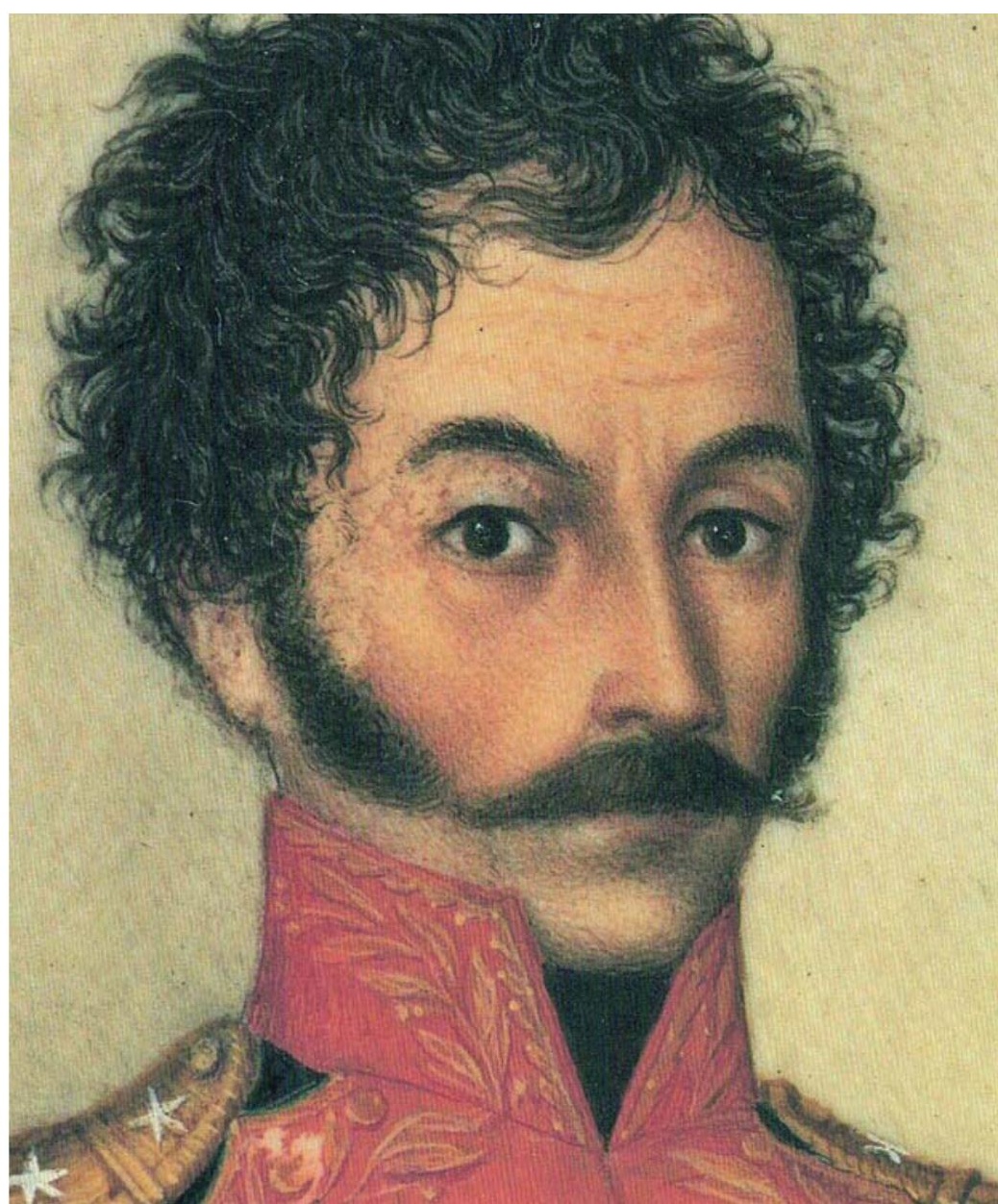


ט

OSORIO BERNAL, Manuel. Galeria biográfica de artistas españoles del siglo XIX. (Re-edição facsimilar 18681869). Madrid: Librería Gaudí Argensola; 1975, p. 705.

Enciclopedia del Arte en América (ob. cit.), tomo 5, s.p.

Caracas: Ed. Macanao; 1991. Cf. PALENZUELA, Juan Carlos. "Bolivar em I82l", em El Nacional. Caracas: 28 de janeiro de 1992 e BURELLI RIVAS, Miguel. "Bolívar em Carabobo", em El Universal. Caracas: 6 de janeiro de 1992.

BARROSO, Manuel. "Uma polêmica la luz da história: de Guayaquil e não de Carabobo devería chamar-se 0 livro de Boulton", em El Nacional. Caracas: 24 de fevereiro de 1992. consegue decifrar-la, apesar de que Duarte, em consulta pessoal, indicara-lhe que bem poderia ser a abreviatura de Guayaquil.

O nome na Espanha corresponderia a um José Anselmo Yáñez quem apresentou quadros a óleo na Exposição da Galícia no ano de 1858, e alcançou na mesma uma menção honrosa. ${ }^{53}$

Se fosse americano corresponderia a José Anselmo Yáñez, nascido em Quito com atividade em Lima até 1830, onde deixa um esboço para La tragédia de San Pedro Alejandrino ou La muerte del Libertador e onde morre em $1860 . .^{54}$ Ambas as opções são rechaçadas por Boulton, mas ao publicar seu livro com o título Bolivar de Carabobo ${ }^{55}$ há quem Ihe responda, precisamente, por esta abreviatura que só poderia significar Guayaquil. ${ }^{56}$

Como toda investigação que se estime válida, nunca há um final e mais quando resulta muito comum que ao melhor caçador the escape a lebre. Vai para Boulton nosso mais sincero agradecimento por tudo que se aprendeu sobre Bolivar e no que nos deixa por aprender.

\section{$\Gamma$}

ROLDÁN ESTEVA-GRILLET é docente associado da História de Arte Latino-americana na Escola de Artes da Universidade Central da Venezuela. Licenciou-se em Letras Hispano-americana na Universidade dos Andes (Mérida, VZLA), realizou estudos de pós-graduaçăo na Universidade dos Estudos de Bolonia (tália) e na Universidade Nacional Autônoma do México. Foi pesquisador e curador da Galeria de Arte Nacional, sendo curador de várias exposiçoes sobre arte venezuelana em outros museus da capital e da provinicia. Publicou vários livros sobre sua especialidade, além dos citados no artigo encontra-se: Para uma crítica del gusto em Venezuela, El dibujo em Venezuela (estúdio y antología), Julián Oñate y Juarez, um pintor de ultramar em el arte latinoamericano del siglo XIX. 